\section{Head Office Purchases New Computer}

With the generous assistance of the Cariboo Section, Head Office was able to purchase a 386 , some software and a laser printer. The staff are very grateful to the section for their generosity, in the form of $\$ 2,000.00$.

C.A. Lee, R.P.F.

\section{Working Group Technical Session - 1991 Annual Meeting}

Following consultation with members, the Forest Economics and Policy, and Forest Pest Control working groups have agreed to hold a joint technical session at the 1991 CIF Annual General Meeting in Toronto. The title of the session is:

\author{
Forest Pest Management In Canada: Status, Impact \\ Levels, and Economic Benefits.
}

Two speakers will address the topic at the technical session, scheduled for September 23, 1991, from 10:30 to 12:00.

Dr. David McLean, Forestry Canada - Maritimes Region, will provide an overview of forest pest status and levels of impact in Canada. Dave is a highly respected research scientist with substantial experience in forest pest management R\&D.

Mr. Marvin Stemeroff, Deloitte \& Touche - Guelph, Ontario, will discuss the economic benefits of forest pest management. The paper will draw heavily from Marvin's recent contract with Forestry Canada to examine the economic benefits of pest management.

Erroll Caldwell, Chair - Forest Pest Control Grant Milne, Chair - Forest Economics and Policy

\title{
Forest History Associations
}

The forestry profession in Canada has always had a few members who were interested enough in forest history to ensure important events were documented and recorded. Some of the more noteworthy are A.H.D. Ross, K.G. Fensom, Dean C.D. Howe, Dean J.W.B. Sisam, Ralph S. Johnson, E. Caldwell and, more recently, Dr. Peter Murphy, W. Young, F. Matte, G. Paillé and J.H. Cayford.

Several attempts have been made to create forest history societies. The Forest History Association of British Columbia, (F.H.A. of B.C.) of which W. Young is President, is the most prominent in Canada. It is an organization with over 400 members committed to the conservation of the Province's forest history and to the promotion of a greater awareness and appreciation of that history. The Association publishes a quarterly Newsletter devoted to the subject.

The Directors of the F.H.A. of B.C. request the CIF/IFC and all its Sections to consider devoting a portion of future annual meetings to some pertinent aspect of forest history. With the controversy and conflict that seem to be part of the current scene respecting use of resources in British Columbia and elsewhere, the knowledge and appreciation of the roots, traditions and history of the forest sector have never been more important.

Foresters in the U.S.A. founded "The Forest History Society" in 1946. It is a nonprofit educational institute that advances historical understanding of mankind's interaction with the forest environment through programs in research, publication, service, library and archival collecting. It publishes a quarterly journal, "Forest and Conservation History.' Several Canadian foresters are active members of this Society.

In 1987 the CIF/IFC established an Archival Committee. It is now developing a program to preserve pertinent records for archival and historical study.

Why not do something about Historical Records?

The F.H.A. of B.C. is asking this question and contends that there is a greater historical conscience in the forest industry now than ever before. But HOW TO DO IT is the perplexing problem faced by corporations, logging companies and mill owners who are concerned about preserving their own records. Faced with a mass of records - legal documents, minutes, correspondence, office files, financial records, ledgers, journals, personnel records, reports, photographs, circulars and publications - management will require advice on what to destroy and what to keep and how to make accessible what is kept. Decisions must be made on whether to establish an archival program and an accompanying records management program or to donate the material to an archive.

Whether it be large or small, advice on how to develop your own archives can be obtained from various sources. The British Columbia Archives and Record Service has an outreach program that offers advice to institutes managing their records. If you wish to donate your records, there are a variety of considerations and options. Nevertheless, it is preferable to retain records created in a region or area in that location, if suitable facilities exist.

The F.H.A. of B.C. offers further advice on what companies can do under the heading "What to do 'til the archivist comes."

- From the beginning, more companies should have a sense of history. Many either keep everything or throw everything out. One is almost as bad as the other, for even a few years' accumulation of everything assumes unmanageable, overwhelming proportions.

- Some experts say that only $5 \%$ of records created by a business are worth preserving, and preservation of most is dictated either by law or common sense. An idea of the material that should be kept to provide a balanced history of a company follows:

- the company charter, papers of incorporation, partnership agreement, licence, whatever legal documents record the establishment of the firm.

- correspondence and papers of the company's founders (and succeeding key executives), both business and personal, relating not only to company business and philosophy, but also to its place within the industry, and community, and 
the executives' activities in industry, civic, charitable and political spheres, as well.

- minutes of meetings of the board, shareholders, executives.

- property records: land and building purchases, sales, leases.

- stock and bond records.

- annual reports, financial records, annual budgets, ledgers.

- policy statements pertaining to all departments.

- personal records: a sampling showing the size of the work force at various stages, salary and wage scales, fringe benefits, etc.

- labor agreements.
- production records: a representative sampling of products, outlines of production layouts and methods, etc.

- advertising: a sampling of advertising in all media, promotion pieces, and public relations campaigns.

- company publications, internal and external, and speeches.

- clippings from newspapers and magazines reporting on the company's activities.

- photographs of the company's board, executives, employees at work, premises, interior and exterior, and significant events.

D.R. Redmond, Chairman Archival Committee

\section{Report on Sustainable Development Questionnaire}

The questionnaire was sent to all CIF/IFC Sections. Fourteen replies were received. Two of these were from the Maritime Section, one for New Brunswick, and one for Prince Edward Island. At least one completed questionnaire was received for each province. One reply stated that because the questions were subjective, and because the province has diverse conditions and inventories the questionnaire could not be satisfactorily completed. Diversity, or other factors, caused some replies from provinces with multiple sections to vary on particular questions. A number of sections had difficulty in providing definitive answers to one or more questions.

Although the information was not gathered in a manner consistent with scientific polling methods and should not be used in absolute terms, it does identify several consistent and important trends about how the Institute's Sections view the present state of forestry in Canada. Three subjects clearly stand out as ones to which the CIF/IFC must address its attention and upon which action is immediately required. The three are: forest regeneration, forest inventory, and forestry education. In a broad sense these, in order, may be said to pertain to the forest, to forestry, and to people.

\section{Forest Regeneration}

Our sections say that we do not know enough about how our forests are regenerating. They say we must improve upon our knowledge of our forests' regeneration in order to properly practice forestry in our country. They also say that realistic free to grow standards are needed as one particularly important aspect of the forest regeneration question.

\section{Forest Inventory}

Our Sections report that generally our knowledge of timber inventory is quite good, although there is plenty of room for improvement. They say our inventory on the wildlife and wildlife habitat components of our forests is fair but requires much work, together with wildlife biologists and managers, to give them proper consideration in our forest management plans and operations. But they say that we are very weak in matters of our forest inventory that pertain to recreation and ecology. While we cannot flag in our efforts on timber and wildlife inventory matters we must also develop satisfactory information on recreation and ecology for use in our forestry work.

\section{Forestry Education}

Our Sections have identified education as one of their prime concerns. They say continuing education for forestry people is essential, perhaps in conjunction with the Registered Professional Foresters associations.

They also indicate that we must provide better information to the public in order for them to make more informed decisions about forestry and forest management.

\section{Recommended Action}

Address forest regeneration, forest inventory, and forestry education in our strategic plan. Use our questionnaire responses in a general way to support efforts we make with government, industry, and other forestry organizations to address the three identified subjects but treat our Sections replies as given by members for the Institute's use and not as public documents. References to our questionnaire response should only be to identify trends or in a collective sense rather than point to specific individual replies. Concentrate our efforts in the near future to the three identified subjects because we have not resources to do more effectively.

It is suggested that the Minister of Forestry, Canada and the Provincial Forestry Ministers should be one focus of our efforts. It is suggested that industry should be another focus, one that can probably best be addressed together with the Canadian Pulp and Paper Association and other industry organizations although direct approaches by our Institute to individual companies may prove valuable. It is suggested that the subject of forestry education be addressed in conjunction with the Canadian Forestry Association, the Registered Professional Foresters Associations, and other pertinent organizations. It is suggested that special opportunities such as National Forest Week and the "Parliamentary Forum on Canada's Forests" be used to present and advance our case.

This report has been prepared by Arden Whidden with appreciation for the valuable assistance given by Susan Hruszowy, Chris Lee, and Anthony Rotherham in assessing the response from the Sections. 